Western North American Naturalist 70(4), (C) 2010, pp. 490-499

\title{
RABBIT ABUNDANCE RELATIVE TO RAINFALL AND PLANT PRODUCTION IN NORTHERN CHIHUAHUAN DESERT GRASSLAND AND SHRUBLAND HABITATS
}

\author{
David C. Lightfoot ${ }^{1}$, Ana D. Davidson² ${ }^{2}$ Christopher M. McGlone ${ }^{3}$, and Dara G. Parker ${ }^{4}$
}

\begin{abstract}
Rabbit abundance patterns in the North American Southwest are poorly known, particularly relative to the potentially important influences of rainfall and plant production. We conducted a 10-year study on the comparative densities of black-tailed jackrabbits (Lepus californicus) and desert cottontail rabbits (Sylvilagus audubonii) in relation to annual rainfall and plant production in both black grama (Bouteloua eriopoda) grassland and creosotebush (Larrea tridentata) shrubland habitats in the northern Chihuahuan Desert. We found that both species of rabbits were more abundant in black grama grassland than in creosotebush shrubland and that plant production was positively correlated with rainfall at both habitats. However, rabbit densities were not positively correlated with rainfall or plant production in either habitat. In fact, both species of rabbits exhibited gradual, multiyear changes in abundance rather than the patterns of high annual variation observed in desert rodent communities. Our findings of no significant relationship between plant production and rabbit densities indicate that rabbit abundance in the northern Chihuahuan Desert may not be strongly regulated by short-term, bottom-up effects of annual variation in plant production. Long-term trends indicate that other factors such as disease or predation may be equally or more important. We suggest that future research evaluate both top-down and bottom-up influences to elucidate the temporal dynamics of Chihuahuan Desert rabbit abundance.
\end{abstract}

Key words: aboveground net primary production, desert grassland, desert shrubland, ENSO events, hares, habitats, Lagomorpha, Lepus, densities, precipitation, rabbits, Sylvilagus.

REsumen.-Se conoce poco sobre los patrones de abundancia de conejos desérticos en el suroeste de Norte America, particularmente en relación con las influencias potencialmente importantes de la precipitación y la producción de plantas. Llevamos a cabo una investigación de diez años sobre la densidad relativa de la liebre de California (Lepus californicus) y el conejo cola de algodón (Sylvilagus audubonii) en los hábitats tanto de pradera de grama negra (Bouteloua eriopoda) como de matorral de gobernadora (Larrea tridentata) en el norte del Desierto Chihuahuense, en relación con la precipitación y la producción anuales. Encontramos que ambas especies de conejo fueron más abundantes en la pradera de grama negra que en el matorral de gobernadora, y que la producción de plantas estuvo correlacionada positivamente con la precipitación en ambos hábitats. Sin embargo, las densidades de conejos no estuvieron correlacionadas positivamente con la precipitación o con la producción de plantas en ninguno de los dos hábitats. De hecho, en cuanto a la fluctuación de su abundancia, las dos especies de conejo exhibieron tendencias graduales a lo largo de varios años, en comparación con los patrones de gran variación anual que se han observado en comunidades de roedores desérticos. La falta de una relación significativa entre la producción de plantas y la abundancia de conejos, indica que la abundancia de conejos en el norte del Desierto Chihuahuense no está fuertemente regulada por los efectos ascendentes a corto plazo de la variación anual en la producción de plantas. Los cambios reflejados en las tendencias a largo plazo indican que otros factores como las enfermedades o la depredación pueden ser de igual o mayor importancia, y sugerimos que investigaciones futuras deberán evaluar tanto las influencias ascendentes como las descendentes para entender las dinámicas temporales en la abundancia de conejos del Desierto Chihuahuense.

Rabbit abundance patterns have been studied relative to predator-prey and host-disease cycles (Clark 1972, Wagner and Stoddart 1972, Dwyer et al. 1990, Reddiex et al. 2002, Bartel and Knowlton 2005) and rabbit pest outbreaks (Wood 1980, Wilson et al. 2002). However, the basic patterns over space and time of North
American desert rabbit abundance remain poorly understood. In contrast, considerable research has been directed toward the study of desert rodent community ecology and abundance. This research on desert rodents addresses aspects of community composition (Brown et al. 1986, Brown and Zeng 1989,

\footnotetext{
${ }^{1}$ Department of Biology, University of New Mexico, Albuquerque, NM 87131. E-mail: dlightfo@unm.edu

${ }^{2}$ Instituto de Ecología, Universidad Nacional Autónoma de México, Apdo Postal 70-275, México, D.F. 04510

${ }^{3}$ Ecological Restoration Institute, Northern Arizona University, Flagstaff, AZ 86011.

${ }^{4}$ Department of Biology, New Mexico State University, Las Cruces, NM 88003.
} 
Reichman 1991) and the relative effects of bottom-up (food resources: Beatley 1969, 1974, Reichman 1975, Brown and Zeng 1989, Whitford and Steinberger 1989, Brown and Heske 1990, Hunter and Price 1992, Power 1992, Ernest et al. 2000) and top-down (predation: Longland and Price 1991, Kotler et al. 1998, Meserve et al. 2003) influences on rodent densities. Generally, positive relationships exist between desert rodent densities and variation in annual rainfall, and presumably subsequent bottom-up effects of plant production (Beatley 1969, 1974, Whitford and Steinberger 1989, Ernest et al. 2000, Meserve et al. 2003). The relative importance of bottom-up and top-down regulation of population dynamics and community organization has been of great interest in ecology. Abiotic factors are thought to be especially important in arid systems because limited rainfall controls the availability of resources. The pulse-reserve model for arid systems suggests strong bottom-up control of net primary production and in turn abundance of consumers (Reynolds et al. 2004).

The black-tailed jackrabbit (Lepus californicus) and the desert cottontail (Sylvilagus audubonii) are the 2 common desert rabbit (Lagomorpha) species of the North American Southwest. Both species occur across a wide variety of habitats but prefer open semidesert mixed grass and shrublands, with cottontails additionally favoring riparian and scrub woodlands (Anderson 1972, Schmidly 1974, Findley et al. 1975, Desmond 2004). Jackrabbits and cottontails are abundant, medium-sized mammals of Chihuahuan Desert landscapes and are known to serve as important food resources for predators such as coyotes and raptorial birds (Wagner and Stoddart 1972, Henke and Bryant 1999, Cartron et al. 2004, Bartel and Knowlton 2005). Rabbits also are known to have significant impacts through herbivory on vegetation composition and structure (Norris 1950, Steinberger and Whitford 1983, Clark and Wagner 1984, Gibbens et al. 1993, Lopez-Portillo 1996, Martinez and Lopez-Portillo 2003). However, ecological studies that document the multiyear temporal patterns of Chihuahuan Desert rabbit abundance are few (Davis et al. 1975). Portales et al. (2004) examined short-term relationships between environmental variables and blacktailed jackrabbit reproduction; yet, we are not aware of any studies that have quantitatively related rabbit abundance trends to temporal variation in bottom-up environmental influences, such as rainfall and plant production, over multiple years.

The Chihuahuan Desert is characterized by a mosaic of desert grasslands and shrublands. Black grama (Bouteloua eriopoda) grasslands and creosotebush (Larrea tridentata) shrublands are common throughout the northern Chihuahuan Desert (Brown 1982, Havstad et al. 2006), and each provides different habitat structure and functional responses to rainfall. Black grama grasslands provide relatively low and homogenous vegetation structural profiles, and the shallow-rooted herbaceous vegetation grows quickly after rainfall (Ludwig 1986, Whitford 2002). Creosotebush shrublands provide taller vegetation profile habitats, but with fewer herbaceous plants. The deep-rooted perennial shrubs do not respond immediately to rainfall but rather to longer-term changes in deep soil moisture (Schlesinger et al. 1990, Reynolds et al. 2004). Fundamental differences in these habitat types may differentially influence rabbit populations; yet, studies that comparatively examine temporal trends of rabbit densities in relation to rainfall and plant production in grassland and shrubland habitats are lacking.

Temporal variation in northern Chihuahuan Desert rainfall is high, but most annual rainfall occurs during late summer (Havstad et al. 2006). El Niño Southern Oscillation (ENSO) events cause additional variable, multiannual shifts from opposing El Niño to La Niña rainfall patterns (Holmgren et al. 2001, Brown and Ernest 2002, Meserve et al. 2003), which drastically change interannual ecosystem productivity. This process is particularly pronounced in arid systems, resulting in pulse-reserve ecosystem dynamics (Reynolds et al. 2004). Plant production in the northern Chihuahuan Desert is also variable over space and time relative to quantities, duration, and seasonal timing of precipitation and to spatial variation in landscape geomorphology and soils (Ludwig 1986, Havstad et al. 2006).

The purpose of this study was to examine the abundance of black-tailed jackrabbits and desert cottontails in both grassland and shrubland habitats from a site in the northern Chihuahuan Desert in relation to measures of precipitation and aboveground plant production. Our primary research questions were the following: (1) Do the 2 habitats support different densities of each rabbit species? (2) How do the changes 


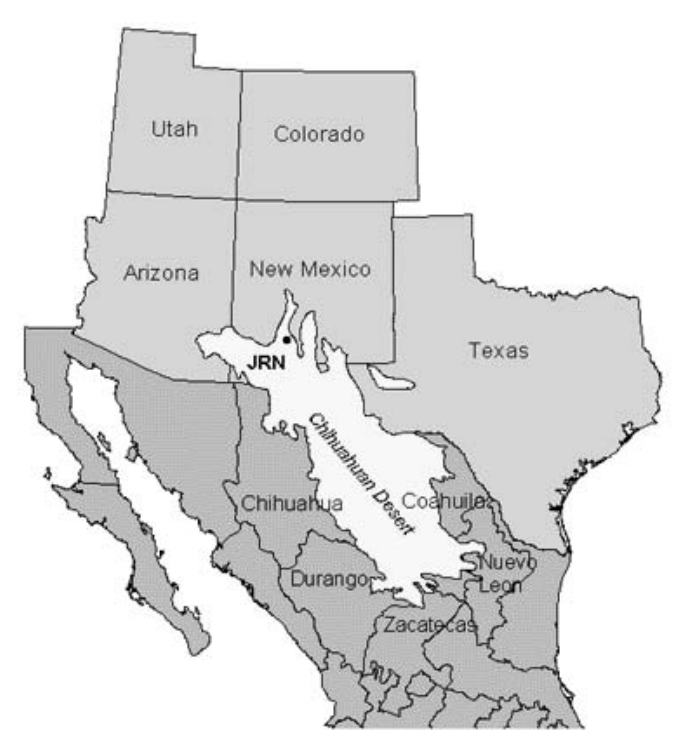

Fig. 1. Jornada Basin study site location (JRN), New Mexico.

in density of each rabbit species over time compare between grassland and shrubland habitats? And (3) do densities of each rabbit species vary in relation to rainfall and plant production over time; and if so, how does this relationship compare between grassland and shrubland habitats?

\section{METHODS}

Study Sites

This research was conducted in the Jornada Basin in the Rio Grande Rift valley of the northern Chihuahuan Desert in southern New Mexico (Fig. 1). One study site was located in black grama grassland on a sandy plain $\left(32^{\circ}\right.$ $35^{\prime} \mathrm{N}, 106^{\circ} 51^{\prime} \mathrm{W}, 1340 \mathrm{~m}$ elevation; Fig. 2A) and the other in adjacent creosotebush shrubland on a gravelly, lower piedmont slope $\left(32^{\circ} 30^{\prime} \mathrm{N}\right.$ $106^{\circ} 12^{\prime} \mathrm{W}, 1340 \mathrm{~m}$ elevation; Fig. 2B). Both study sites were situated adjacent to aboveground net primary production (ANPP) study plots on the existing National Science Foundation, Jornada Basin Long-Term Ecological Research site (Huenneke et al. 2001, Havstad et al. 2006). The creosotebush site was dominated by creosotebush shrubs along with the less common woody shrubs honey mesquite (Prosopis glandulosa) and tarbush (Flourensia cernua), the perennial grass bush muhly (Muhlenbergia porteri), and many species of annual forbs.
The soils consisted of gravelly loams. The black grama grassland site was dominated by perennial black grama grass along with other common perennial grasses such as spike dropseed (Sporobolus contractus) and threeawn (Aristida purpurea), widely scattered honey mesquite and broom snakeweed (Gutierrezia sarothrae), soaptree yucca (Yucca elata), and many species of annual and perennial forbs. The soils consisted of sandy loams.

\section{Sampling Design}

Data on rabbits, vegetation, and rainfall were collected over a 10-year period from 1996 to 2005. Rabbit species composition and densities were estimated from road-transect surveys (Buckland et al. 1993) at each study site, once during the middle of spring (April/May) and once during fall (October/November) to correspond with spring and fall plant measurements. Over the 10-year study period, the seasonal surveys resulted in 20 samples from each of the 2 study sites. The survey roads were remote, secondary gravel roads on the Chihuahuan Desert Rangeland Research Center (New Mexico State University) and the Jornada Experimental Range (USDA-ARS), with no nighttime automobile traffic to confound observations. These were the only roads available to survey for each study area. One 10-km road transect was sampled through each creosotebush and grassland habitat. Although each of the two $10-\mathrm{km}$ transects were technically a sample size of one each, both $10-\mathrm{km}$ transects traversed varied landscapes and provided good representations of landscape variation across both the creosotebush shrubland and grassland environments.

A field crew consisting of a driver/data recorder and 2 observers drove slowly in an open-bed pickup truck (approximately $15 \mathrm{~km}$. hour $^{-1}$ ) along each road segment, starting about one hour after sunset. The vehicle's trip odometer was set to zero at the start of each road transect. The 2 observers in the back of the truck scanned the side of the road for rabbits, each using a 1,000,000-candlepower spotlight. The observers shined the light beam in a $90^{\circ}$ arc from the road ahead to the area perpendicular to the truck and up to $100 \mathrm{~m}$ out from the road. Each time a rabbit was observed, the driver recorded the odometer mileage and time, and the rabbit was identified to species. The perpendicular distance from the center 

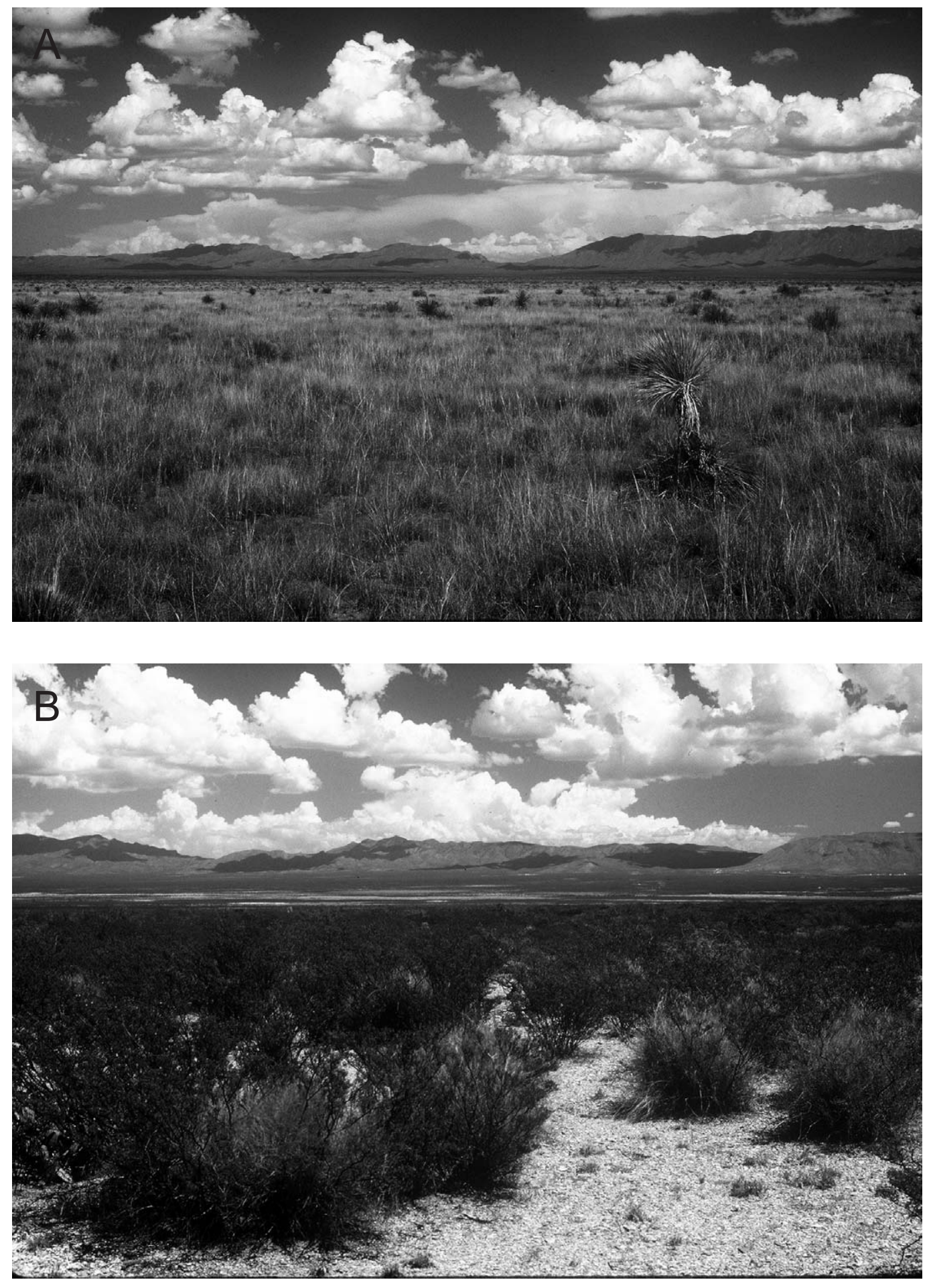

Fig. 2. Photographs of the Jornada Basin: (A) black grama grassland and (B) creosotebush shrubland study sites. 
of the road to the rabbit was measured to the nearest meter with a metric infrared-laser range finder. Only observations within $100 \mathrm{~m}$ of the road were recorded to avoid potential errors associated with long-distance observations. Smith (1990) found black-tailed jackrabbits to be most active on nights with a moon, and we (McGlone and Lightfoot, unpublished data) found that rabbit activity in the Jornada Basin was significantly greater on nights with a full moon. In order to help standardize environmental conditions at sampling times, we sampled only on full-moon nights for this study. We also sampled only when skies were mostly clear and winds were light $(<10 \mathrm{mph})$.

Precipitation was measured from LTER meteorological stations associated with ANPP plots located adjacent to each study site. Rainfall data were collected monthly at each of the sites by using tipping-bucket rain gauges. For this study, the monthly rainfall amounts from November to April were combined to represent the winterspring rainfall period, and the monthly rainfall amounts from May to October were combined to represent the summer rainfall period. Over the 10-year study period, these seasonal time intervals resulted in a total of 20 precipitation samples from each of the 2 study sites.

ANPP was measured from the Jornada Basin LTER study plots, and biomass values were calculated from volumetric vegetation measurements as described by Huenneke et al. (2001). Three replicate vegetation measurement plots measuring $70 \mathrm{~m}$ on each side were established in each vegetation community type by the Jornada Basin LTER program. Each vegetation plot consisted of 21 permanently marked $1-\mathrm{m}^{2}$ quadrats. Vegetation was measured from each $1-\mathrm{m}^{2}$ quadrat according to methods of Huenneke et al. (2001), which consisted of volumetric measurements (vertical height and horizontal cover) of foliage canopy by species on each quadrat. Measurements were taken in January, April, and September of each year to capture seasonal plant growth. The same range of volumes of plant species foliage as measured on the study plots was harvested adjacent to, but not on, the study plots. Harvested plant biomass samples were oven dried, and regression equations of dry weight by volume were developed to relate the harvested plant biomass back to the volumetric values measured on the study plots. This procedure yielded biomass production, or ANPP $\left(\mathrm{g} \cdot \mathrm{m}^{-2}\right)$ estimates for the study plots by plant species for each season or each year. The plant species were then categorized into functional groups by growth form (grasses, forbs, or shrubs) and by life history (annuals or perennials). ANPP was determined for the winter-spring period (November-April) and for the summer period (May-October). Over the 10year study period, those 2 seasonal measurements per year resulted in a total of 20 samples for ANPP from each of the 2 study sites. ANPP data generated from the 2 years prior to the rabbit surveys were also used to evaluate lag responses to productivity of previous years.

\section{Data Analyses}

The rabbit count and perpendicular distance measures were used to estimate densities (number of individuals per hectare) for each of the 20 survey dates with the analytical program DISTANCE (Buckland et al. 1993). To avoid observer error between the grassland and shrubland habitats, due to shrubs affecting the abilities of observers to detect rabbits, we limited our data analysis to all observations $\leq 20 \mathrm{~m}$ from the road for both habitats.

We partitioned the rainfall and the ANPP data into 4 different time periods to examine lag-time relationships between previous rainfall and plant production and lag-time relationships between previous plant production and rabbit densities. We examined data at intervals from the previous 0-6 months, 6-12 months, 12-18 months, and 18-24 months. Over the 10-year study period with 2 seasons of data (spring and fall) per year, there were a total of 80 time intervals for lag and nonlag response times.

We used the Shapiro-Wilk test (SAS Institute, Inc. 2005; Proc Univariate) to test all data sets for normal distributions. The precipitation and ANPP data were normally distributed, so we used standard parametric linear regression (SAS Institute, Inc. 2005; Proc Reg) to test for significant relationships between rainfall (independent variable) and plant production (dependent variable). We examined relationships between the total ANPP summed over all plant species and the ANPP partitioned by plant life-forms (e.g., grasses, forbs, etc.) and plant life histories (annual or perennial). The rabbit density data were not normally distributed, so we used a nonparametric Spearman-rank correlation analysis (SAS Institute, Inc. 2005) to test for simple linear relationships between rainfall, ANPP, and rabbit 

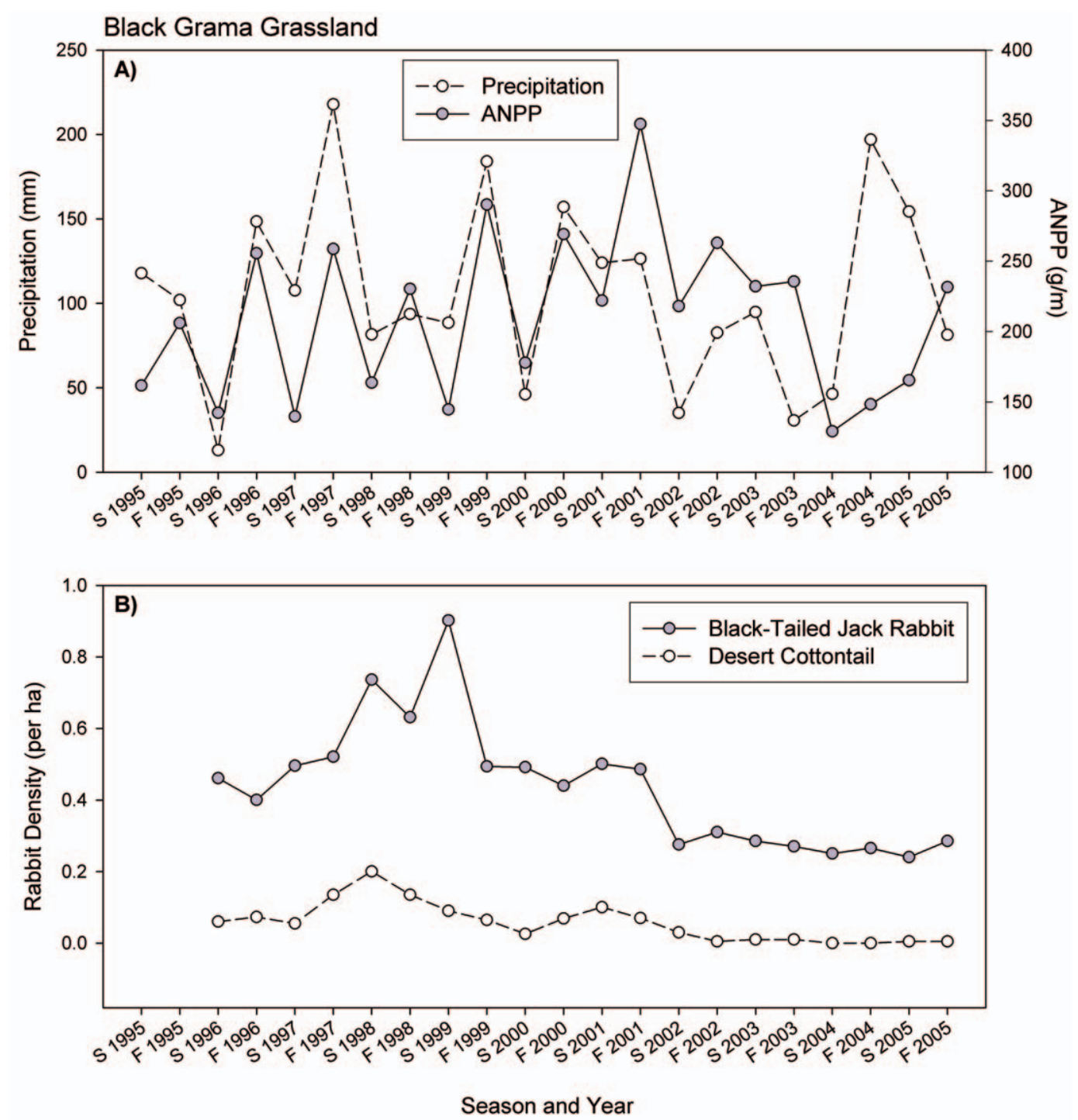

Fig. 3. (A) Precipitation and aboveground net primary productivity (ANPP; 1995-2005) and (B) rabbit population densities (1996-2005) on the black grama grassland site for the fall (F) and spring (S) seasons.

densities over the 10-year period. We used an alpha level of 0.05 for rejecting the null hypotheses of no significant regression or correlation relationships.

\section{RESUlTS}

Seasonal precipitation and ANPP varied considerably over the study period, but temporal patterns were similar for both study sites (Figs. 3A, 4A). Several ENSO events occurred over the duration of the study. The study began during a dry period in 1995, which was followed by wet periods in 1998, 1999, and 2005, with additional dry periods in 1997 and 2000-2003. Years 1998, 2004, and 2005 were El Niño periods, with above-average precipitation, and 1995, 1996, and 2000-2003 were La Niña years, with belowaverage winter precipitation. Summer rainfall relative to winter rainfall was particularly high during those years. Total ANPP at the grassland site was significantly positively predicted by the previous $6-12$ months of rainfall $\left(\mathrm{R}^{2}=\right.$ $\left.0.24, F_{19}=5.68, P=0.03\right)$, but not by the 

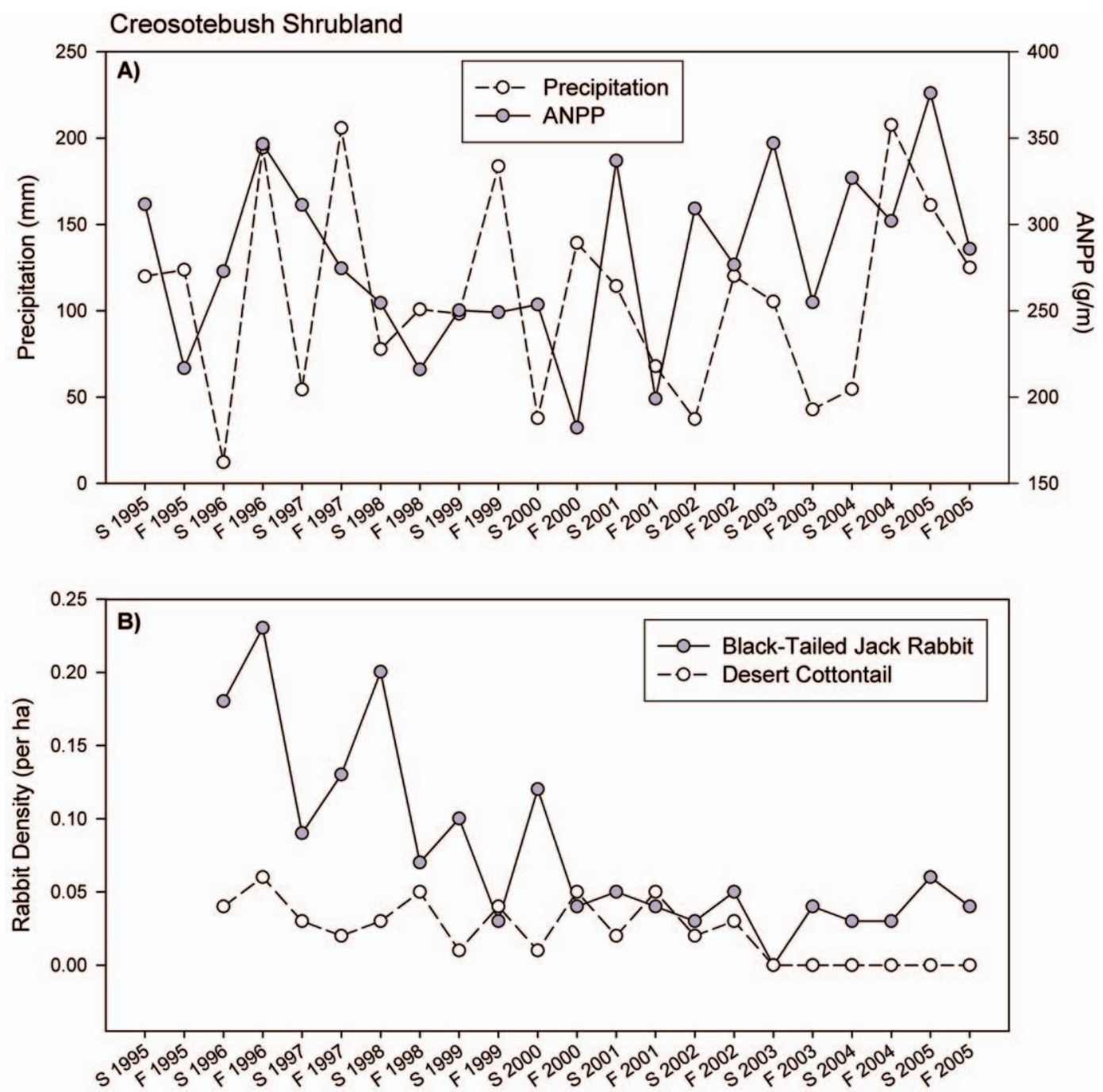

Season and Year

Fig. 4. (A) Precipitation and aboveground net primary productivity (ANPP; 1995-2005) and (B) rabbit population densities (1996-2005) on the creosote shrubland site for the fall (F) and spring (S) seasons.

previous 0-6 months of rainfall. Among the various plant life-forms and life histories, only perennial grass production was significantly predicted by rainfall at the grassland site $\left(\mathrm{R}^{2}\right.$ $\left.=0.19, F_{19}=4.19, P=0.05\right)$, and only by the previous 6-12 months of rainfall. Total ANPP at the shrub site was significantly positively predicted by the previous $6-12$ months of rainfall $\left(\mathrm{R}^{2}=0.28, F_{19}=7.19, P=0.01\right)$, and perennial shrubs $\left(\mathrm{R}^{2}=0.34, F_{19}=9.28, P=\right.$ $0.007)$ and perennial forbs $\left(\mathrm{R}^{2}=0.19, F_{19}=\right.$ $4.28, P=0.05)$ were significantly predicted by rainfall from the previous 6-12 months. Annual grass was the only vegetation at the shrubland site significantly predicted by rainfall from $0-6$ months previous $\left(\mathrm{R}^{2}=0.27, F_{19}=6.62, P=\right.$ 0.02 ). We did not find any significant relationships between rainfall and ANPP beyond 12 months.

Both black-tailed jackrabbits and desert cottontails were generally more abundant at the grassland site than at the shrubland site, and black-tailed jackrabbits were consistently more abundant than desert cottontails (Figs. 3B, 4B). 
Rabbit densities also changed over time at both study sites, but these changes occurred slowly over many years, with little annual fluctuation (Figs. 3B, 4B). Densities were consistently higher at the grassland site, where they peaked in 1999 near $1.0 \mathrm{rabbit} \cdot \mathrm{ha}^{-1}$, then gradually declined to about 0.3 rabbits $\cdot \mathrm{ha}^{-1}$ by 2005 . Initial rabbit densities at the shrub site were near $0.3 \cdot \mathrm{ha}^{-1}$ in 1995 and gradually declined to near $0.1 \cdot \mathrm{ha}^{-1}$ in 2005 . Total combined densities of both rabbit species and those for each rabbit species separately were not significantly $(P>0.05)$ correlated with rainfall from the previous 6 months, 12 months, or $>12$ months from either the grassland or shrubland sites. Total rabbit densities and densities for each species were not significantly correlated with plant production from the previous 6 months or $>6$ months at either study site.

\section{Discussion}

Over the 10-year study period, our data demonstrated that densities of both rabbit species changed gradually over time and that their densities were not positively correlated with short-term, bottom-up annual variation in either rainfall or plant production. This finding contrasts with the documented relationships between rainfall and Chihuahuan Desert rodent abundance (Whitford and Steinberger 1989, Ernest et al. 2000). Chihuahuan Desert rodent assemblages are dominated by granivorous heteromyids that forage largely on the seeds of annual herbs, which are greatly influenced by annual precipitation (Beatley 1969, 1974, Reichman 1975, Brown and Zeng 1989, Whitford and Steinberger 1989, Brown and Heske 1990). Black-tailed jackrabbits, and probably desert cottontails, forage on annual herbs as well as on woody perennial shrubs and are known to switch from foraging on herbs to woody shrubs during dry periods (Steinberger and Whitford 1983, Lopez-Portillo 1996, Martinez and LopezPortillo 2003). Woody shrubs provide temporally stable food and moisture resources regardless of short-term responses to variation in rainfall as predicted by the pulse-reserve model. Therefore, Chihuahuan Desert rabbits may not be as influenced by short-term, bottom-up annual plant production in the way rodents are. These results provide some of the first insights into relationships between rabbit abundance and bottom-up influences in North America.
Portales et al. (2004) demonstrated that the reproductive condition of the black-tailed jackrabbit was positively correlated with short-term rainfall and other environmental factors in the Mapimi Basin in the central Chihuahuan Desert. Rainfall and the immediate subsequent production of plant forage may be important to rabbit reproduction, as it is for desert rodents (Beatley 1969, 1974, Reichman 1975, Reichman and Van De Graff 1975), but other factors may be more important in determining the ultimate annual population levels in the Chihuahuan Desert. Predation and/or disease probably complicated the positive relationship between rainfall, plant production, and rabbit density increases. Predation has been documented as a factor in declining black-tailed jackrabbit densities (Clark 1972, Wagner and Stoddart 1972, Bartel and Knowlton 2005), and diseases, such as tularemia and myxomatosis, are known to negatively affect rabbit densities (Dwyer et al. 1990, Reddiex et al. 2002). However, we had no data on important predators or disease organisms from our study area. Still, the fact that densities of both rabbit species changed gradually over time indicates that some other factor(s), operating over time scales of more than one year were influencing the rabbit abundance. Both species of rabbits exhibited overall declines in density over the 10-year duration of the study.

Foraging behavior of black-tailed jackrabbits appears to be confounded by predation risk. McAdoo et al. (1987), working in Nevada, found black-tailed jackrabbit densities and foraging to be greatest near shrubs and less in large open grassland habitats with similar amounts of food. Ariadna et al. (2003) found higher densities of black-tailed jackrabbits in habitats with both greater food resources and lower predation risk. These studies demonstrate that top-down effects of predators can offset the positive effects of increased food availability. We observed rabbit predators such as coyotes, bobcats, hawks, Golden Eagles, and Great-horned Owls at our study site in the Jornada Basin. All of these predators likely affected the rabbit populations that we studied.

We also found that black-tailed jackrabbits and desert cottontails were more abundant in the relatively open grassland than in the adjacent shrubland. Black-tailed jackrabbits were more numerous than desert cottontail rabbits across both habitats. Black-tailed jackrabbits are known to prefer relatively open habitats with 
some shrub cover (Desmond 2004), presumably so they can visually detect and escape from predators (McAdoo et al. 1987). Desert cottontail rabbits prefer habitats with considerable shrub or low tree cover (Schmidly 1974) in which they presumably hide from predators; yet, we found higher densities of desert cottontail rabbits in the grassland than in the shrubland. The relatively open grama grasslands included scattered mesquite shrubs and soaptree yucca plants which apparently provided adequate cover for both species of rabbits.

Our findings demonstrate that black-tailed jackrabbit and desert cottontail rabbit abundance did change over time, but the changes were long-term, multiyear trends rather than short-term, annual fluctuations. Our findings also demonstrate that rabbit densities were not positively correlated with either rainfall or plant production. Our 10-year sampling period may not have been long enough to provide sufficient data to detect subtle relationships between plant production and rabbit densities or to assess the importance of long-term patterns in rainfall and plant production. Other environmental factors such as predators and disease probably affected Chihuahuan Desert rabbit abundance. More long-term research is needed to understand the relationships between rabbits, climate, weather, plant production, predators, and disease.

\section{ACKNOWLEDGMENTS}

Funding was provided by the National Science Foundation, grant DEB 9527083 for this project and grant DEB 0080412 to the Jornada Basin LTER program. We thank the Jornada Basin LTER field crew members who helped collect the data for this research. John Anderson, Jornada Basin LTER Program Manager, also assisted with all aspects of this research.

\section{Literature Cited}

Anderson, S. 1972. Mammals of Chihuahua: taxonomy and distribution. Bulletin of the American Museum of Natural History 148:149-410.

Ariadna, I.M., L. Hernandez, And J.W. Laundre. 2003. Predation risk and food quantity in the selection of habitat by black-tailed jackrabbit (Lepus californicus): an optimal foraging approach. Journal of Arid Environments 55:101-110.

Bartel, R.J., And F.F. Knowlton. 2005. Functional feeding responses of coyotes, Canis latrans, to fluctuating prey abundance in the Curlew Valley, Utah. Canadian Journal of Zoology 83:569-578.
Beatley, J.C. 1969. Dependence of desert rodents on winter annuals and precipitation. Ecology 50:721-724. 1974. Phenological events and their environmental triggers in Mohave Desert ecosystems. Ecology 55:856-863.

Brown, D.E. 1982. Biotic communities of the American Southwest: United States and Mexico. Desert Plants 4:1-342.

Brown, J.H., D.W. Davidson, J.C. Munger, and R.S. INOUYE. 1986. Experimental community ecology: the desert granivore system. Pages 41-61 in J. Diamond and T.J. Case, editors, Community ecology. Harper \& Row Publishers, New York, NY.

Brown, J.H., And S.K.M. ERnEST. 2002. Rain and rodents: complex dynamics of desert consumers. BioScience 52:979-987.

Brown, J.H., AND E.J. Heske. 1990. Control of a desertgrassland transition by a keystone rodent guild. Science 250:1705-1707.

Brown, J.H., AND Z. ZENG. 1989. Comparative population ecology of eleven species of rodents in the Chihuahuan Desert. Ecology 70:1507-1525.

Buckland, S.T., D.R. Anderson, K.P. Burham, and J.L. LAAKE. 1993. Distance sampling: estimating abundance of biological populations. Chapman and Hall, London, United Kingdom.

Cartron, J.-L.E., P.J. Polechla, and R.R. CoOK. 2004. Prey of nesting Ferruginous Hawks in New Mexico. Southwestern Naturalist 49:270-276.

CLARK, W.R. 1972. Influence of jackrabbit density on coyote population change. Journal of Wildlife Management 36:343-356.

Clark, W.R., AND F.H. WaGNER. 1984. Role of livestock and black-tailed jackrabbits in changing abundance of Kochia americana. Great Basin Naturalist 44:635-646.

Davis, C.A., J.A. Meduin, And J.P. Griffing. 1975. Abundance of black-tailed jackrabbits, desert cottontail rabbits, and coyotes in southeastern New Mexico. Research Report 293, Agricultural Experiment Station, New Mexico State University, Las Cruces, NM.

Desmond, M.J. 2004. Habitat associations and co-occurrence of Chihuahuan Desert hares (Lepus californicus and L. callotis). American Midland Naturalist 151: 414-419.

Dwyer, G., S.A. Levin, AND L. ButTel. 1990. A simulation model of the population dynamics and evolution of Myxomatosis. Ecological Monographs 60:423-447.

Ernest, S.K.M., J.H. Brown, And R.R. Parmenter. 2000 Rodents, plants, and precipitation: spatial and temporal dynamics of consumers and resources. Oikos 88 : $470-482$.

Findley, J.S., A.H. Harris, D.E. Wilson, and C. Jones. 1975. Mammals of New Mexico. University of New Mexico Press, Albuquerque, NM.

Gibbens, R.P., K.M. Havstad, D.D. Billheimer, and C.H. HerbeL. 1993. Creosotebush vegetation after 50 years of lagomorph exclusion. Oecologia 94:210-217.

Havstad, K.M., L.F. Huenneke, and W.H. Schlesinger, EDITORS. 2006. Structure and function of a Chihuahuan Desert ecosystem: the Jornada Basin Long-Term Ecological Research Site. Oxford University Press, Oxford, United Kingdom.

Henke, S.E., and F.C. Bryant. 1999. Effects of coyote removal on the faunal community in west Texas. Journal of Wildlife Management 63:1066-1081.

Holmgren, M., M. Scheffer, E. Ezcurra, J.R. GutierREZ, AND G.M.J. Mohren. 2001. El Niño effects on 
the dynamics of terrestrial ecosystems. Trends in Ecology and Evolution 16:89-94.

Huenneke, L.F., D. Clason, and E. Muldavin. 2001. Spatial heterogeneity in Chihuahuan Desert vegetation: implications for sampling methods in semi-arid ecosystems. Journal of Arid Environments 47:257-270.

Hunter, M.D., AND P.W. PricE. 1992. Playing chutes and ladders: heterogeneity and the relative roles of bottom-up and top-down forces in natural communities. Ecology 73:724-732.

Kotler, B.P., J.S. Brown, R.J. Smith, and W.O.I. Wirtz. 1998. The effects of morphology and body size on rates of owl predation on desert rodents. Oikos 53: $145-152$.

Longland, W.S., AND M.V. Price. 1991. Direct observations of owls and heteromyid rodents: can predation risk explain microhabitat use? Ecology 72:2261-2273.

Lopez-Portillo, J. 1996. Stem demography of Prosopis glandulosa var. torreyana in vegetation arcs and associated bare areas. Journal of Vegetation Science 7: 2261-2273.

LuDwiG, J.A. 1986. Primary production variability in desert ecosystems. Pages 5-17 in W.G. Whitford, editor, Pattern and process in desert ecosystems. University of New Mexico Press, Albuquerque, NM.

McAdoo, J.K., G.J. Longland, G.J. Cluff, and D.A. KLEBENOW. 1987. Use of new rangeland seedlings by black-tailed jackrabbits. Journal of Range Management 40:520-524.

Martinez, A.J., AND J. Lopez-Portillo. 2003. Growth and architecture of small honey mesquites under jackrabbit browsing: overcoming the disadvantage of being eaten. Annals of Botany (London) 92:365-375.

Meserve, P.L., D.A. Kelt, W.B. Milstead, and J.R. GuTiÉRREZ. 2003. Thirteen years of shifting topdown and bottom-up control. Bioscience 53:633-646.

NoRRIS, J.J. 1950. Effect of rodents, rabbits, and cattle on two vegetation types in semidesert range land. New Mexico State University Agricultural Experiment Station, Las Cruces, NM.

Portales, G.L., L. Hernandez, F.A. Cervantes, and J.W. LAUNDRE. 2004. Reproduction of black-tailed jackrabbits (Lagomorpha: Lepus californicus) in relation to environmental factors in the Chihuahuan Desert, Mexico. Southwestern Naturalist 49:359-366.

PowER, M.E. 1992. Top-down and bottom-up forces in food webs: do plants have primacy? Ecology 73:733-746.

Reddiex, B., G.J. Hickling, G.L. Norbury, and C.M. Frampton. 2002. Effects of predation and rabbit haemorrhagic disease on population dynamics of rabbits (Oryctolagus cuniculus) in North Canterbury, New Zealand. Wildlife Research 29:627-633.

Reichman, O.J. 1975. Relation of desert rodent diets to available resources. Journal of Mammalogy 56:731751.
1991. Relation of desert rodent diets to available resources. Pages 311-347 in G.A. Polis, editor, The ecology of desert communities. University of Arizona Press, Tucson, AZ.

Reichman, O.J., And K.M. Van De Graff. 1975. Association between ingestion of green vegetation and desert rodent reproduction. Journal of Mammalogy 56:503506.

Reynolds, J.F., P.R. Kemp, K. Ogle, and R.J. FernánDEZ. 2004. Modifying the pulse reserve paradigm for deserts of North America: precipitation pulses, soil water, and plant responses. Oecologia 141:211-220.

SAS InstituTE, INC. 2005. SAS system for Microsoft Windows. SAS Institute, Inc., Cary, NC.

Schlesinger, W.H., J.F. Reynolds, G.L. Cunningham, L.F. HuenNeKe, W.M. JarReLl, R.A. Virginia, and W.G. WhitFord. 1990. Biological feedbacks in global desertification. Science 247:1043-1048.

SCHMidLY, D.J. 1974. Factors governing the distribution of mammals in the Chihuahuan Desert region. In: R.H. Wauer and E.H. Riskind, editors. Transactions of the Symposium on the Biological Resources of the Chihuahuan Desert region, United States and Mexico. Proceedings and Transaction Series No. 3, U.S. Department of Interior, National Park Service.

SMITH, G. 1990. Home range and activity patterns of blacktailed jackrabbits. Great Basin Naturalist 50:249-256.

Steinberger, Y., AND W.G. Whitford. 1983. The contribution of shrub pruning by jackrabbits to litter input in a Chihuahuan Desert ecosystem. Journal of Arid Environments 6:183-187.

WaGNER, F.H., AND L.C. STODDART. 1972. Influence of coyote predation on black-tailed jackrabbit populations in Utah. Journal of Wildlife Management 36: 329-342.

Whitford, W.G. 2002. Ecology of desert systems. Academic Press, San Diego, CA.

Whitford, W.G., and Y. Steinberger. 1989. The longterm effects of habitat modification on a desert rodent community. Pages 33-43 in D.W. Morris, Z. Abramsky, B.J. Fox, and M.R. Willig, editors, Patterns in the structure of mammalian communities. Texas Tech University Press, Lubbock, TX.

Wilson, J.C., S.J. Fuller, and P.B. Mather. 2002. Formation and maintenance of discrete wild rabbit (Oryctolagus cuniculus) population systems in arid Australia: habitat heterogeneity and management implications. Austral Ecology 27:183-191.

Wood, D.H. 1980. The demography of a rabbit population in an arid region of New South Wales, Australia. Journal of Animal Ecology 49:55-79.

Received 22 September 2009 Accepted 26 April 2010 